\title{
ANALISIS STRATEGI PEMASARAN SAGU KASBI PADA GAPOKTAN PRIMA JAYA DI KELURAHAN JAYA KECAMATAN TIDORE UTARA KOTA TIDORE KEPULAUAN PROPINSI MALUKU UTARA
}

\author{
Nur Azizah \\ Staf Pengajar Faperta Univ. Nuku-Tidore, $\boldsymbol{e}$-mail: -
}

\begin{abstract}
ABSTRAK
Studi ini bertujuan untuk mengetahui peran gapoktan Prima Jaya dalam manajemen operasional pemasaran sagu kasbi, dan mengetahui strategi pemasaran sagu kasbi yang dilakukan Gapoktan Prima Jaya. Penelitian ini dilakukan selama 3 bulan (Februari, Maret, April 2011) di Kecamatan Tidore Utara dengan 8 responden yang dipilih secara purposive. Analisis data yang digunakan adalah deskriptif dan analisa SWOT terhadap faktor-faktor internal dan eksternal Gapoktan Prima Jaya. Berdasarkan hasil penelitian, peranan gapoktan dalam manejemen pemasaran meliputi 1) Kemampuan merencanakan kegiatan 2) Kemampuan melaksanakan dan menaati perjanjian dengan pihak lain 3) Kemampuan memupuk modal dan memanfaatkan modal secara rasional 4) Kemampuan meningkatkan hubungan melembaga dengan KUD dan Koptan 5) Kemampuan memanfaatkan Informasi dan menerapkan teknologi 6) Kemampuan penerapan bauran pemasaran yang terdiri dari produk, harga, promosi dan saluran distribusi. Adapun strategi pemasaran yang perlu dilakukan Gapoktan Prima Jaya adalah: 1) Pengembangan produk sagu kasbi dengan aneka rasa pandan, kenari dan gula merah 2) Menciptakan atribut produk yang menarik 3) Melakukan promosi 4) Membina kerjasama dengan KUD 5) Menciptakan merek produk sagu kasbi yang berbeda dengan pesaing 6) Melakukan pengembangan pasar.
\end{abstract}

Kata Kunci: Strategi, Pemasaran, Produk

\section{PENDAHULUAN}

Pangan merupakan kebutuhan mendasar bagi suatu negara, terutama negara berkembang. Selain itu pangan merupakan hak asasi setiap individu untuk memperolehnya dengan jumlah yang cukup dan aman serta terjangkau. Oleh karena itu, upaya pemantapan ketahanan pangan harus terus dikembangkan dengan memperhatikan sumberdaya, kelembagaan dan budaya lokal. Setiap daerah memiliki potensi pangan yang berbeda-beda, Berbagai jenis pangan tersebar, dikembangkan dan dimanfaatkan oleh masyarakat setempat. Untuk pemenuhan kebutuhan konsumsinya baik sebagai pangan pokok maupun substitusi. Tidore Kepulauan merupakan salah satu kota yang terletak di propinsi Maluku Utara mempunyai potensi pangan dan budaya lokal yang beragam serta potensi masyarakat yang telah mampu memproduksi, mengolah dan mengkonsumsi pangan lokal yang beranekaragam. Selain itu terdapat potensi genetik dari varietas ubi kayu lokal Tidore yang mampu memberikan tingkat produktivitas yang cukup tinggi yaitu 62 ton/ha dibandingkan dengan varietas lainnya dalam sistem pengelolaan tanaman terpadu. Tidore Kepulauan juga merupakan wilayah yang cukup baik untuk mengembangkan komoditi ubi kayu serta memiliki banyak industri pengolahan pangan ubi kayu sebagai salah satu upaya diversifikasi pangan ubi kayu. Berdasarkan data dari Dinas Pertanian dan Kehutanan Kota Tidore Kepulauan, pada tahun 2009 menunjukkan bahwa luas areal yang dimiliki sebesar 700,4 ha dengan jumlah produksi sebesar 972, 8 ton. Industri pengolahan ubi kayu memiliki keterkaitan dengan sektor hulu ( yang meliputi semua aspek seperti pengadaan bahan baku dan 


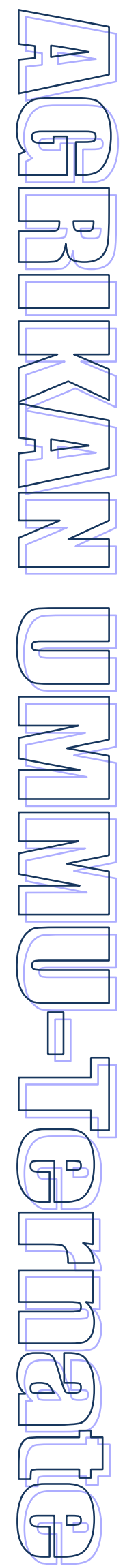

aktifitas produksi ) dan sektor hilir (yang meliputi transportasi dan pemasaran produk).

Ubi kayu merupakan komoditas hasil pertanian yang memiliki potensi baik untuk dikembangkan menjadi berbagai macam produk olahan pangan baik yang dikonsumsi langsung oleh rumah tangga maupun bahan baku untuk industri pangan.

Kegiatan pengembangan agribisnis ubi kayu menjadi sagu kasbi yang dilaksanakan oleh petani yang sekaligus sebagai produsen sagu kasbi tidak pernah terlepas dari berbagai kendala, baik kendala modal, tenaga kerja, pasar, konsumen, teknologi dan manajemen dalam pengelolaan usahataninya.

Gapoktan Prima Jaya merupakan gabungan dari beberapa kelompok petani yang anggotanya merupakan produsen yang bergerak dibidang pengolahan sagu kasbi. Gapoktan Prima Jaya diharapkan dapat meningkatkan bargaining position ( posisi tawar) petani terutama dalam perdagangan hasil perkebunan maupun penyediaan sarana produksi secara kolektif. Namun sejauh ini peran gapoktan Prima Jaya belum berfungsi dengan baik serta belum membawa perubahan yang berarti dalam memecahkan persoalan peningkatan produksi, manajemen, modal, fluktuasi harga dan permintaan pasar. Berdasarkan latar belakang yang telah dikemukakan, maka rumusan masalah dalam penelitian adalah : 1) Bagaimana peranan gapoktan Prima Jaya dalam manajemen operasional pengolahan sagu kasbi di Kota Tidore Kepulauan ? 2) Apakah Strategi Pemasaran Sagu Kasbi yang diperlukan oleh Gapoktan Prima Jaya di Kecamatan Tidore Utara Kota Tidore Kepulauan?

\section{METODE PENELITIAN}

Penelitian ini dilaksanakan di Kota Tidore Kepulauan Propinsi Maluku Utara tepatnya di Kelurahan Jaya yang dilaksanakan mulai pada bulan Februari sampai dengan April 2011. Penentuan lokasi penelitian ini dilakukan secara purposive karena berdasarkan pertimbangan bahwa daerah ini mayoritas penduduknya bermata pencaharian sebagai produsen sagu kasbi yang sudah ada sejak dari dahulu sampai sekarang.

Data yang dikumpulkan dalam penelitian ini meliputi data primer dan data sekunder yang terdiri atas :

1. Data Primer adalah data yang diperoleh langsung dari ketua, pengurus dan para anggota Gapoktan Prima Jaya. Pengisian kuesioner untuk tujuan analisis strategi diberikan kepada informan yang dipilih secara sengaja (purposive) dengan pertimbangan bahwa informan harus memiliki tingkat penguasaan yang tinggi terhadap bidang yang akan diteliti sekaligus permasalahannya. Pemilihan informan dilakukan pada saat dilakukan diskusi terfokus atau FGD dengan beberapa anggota dan pengurus gapoktan. Informan tersebut adalah ketua gapoktan, pengurus gapoktan dan anggota gapoktan sebagai petani yang sebagian sekaligus produsen sagu kasbi. Kriteria penentuan informan dari Gapoktan meliputi : tingkat pendidikan minimal SMP, pengalaman mengolah sagu kasbi minimal 5 tahun, melakukan kegiatan produksi sagu kasbi setiap bulannya, memiliki luas lahan minimal 0,5 ha. Data primer yang dikumpulkan adalah data yang berkaitan dengan peranan gapoktan dalam hal kemampuan merencanakan kegiatan, kemampuan melaksanakan dan menaati perjanjian dengan pihak lain, kemampuan memupuk modal dan memanfaatkan secara rasional, kemampuan meningkatkan hubungan yang melembaga dengan KUD dan Koptan, kemampuan menerapkan teknologi dan memanfaatkan informasi, kemampuan menerapkan bauran pemasaran (produk, harga, saluran distribusi dan promosi)dalammanajemen operasional pemasaran sagu kasbi berupa data tentang jumlah tenaga kerja, data produksi sagu kasbi, visi, misi dan tujuan gapoktan, struktur organisasi gapoktan, program-program gapoktan dalam pengembangan sagu kasbi, jumlah anggota kelompok tani, jumlah pendapatan, tingkat pendidikan, jumlah tenaga kerja, pengalaman berusaha tani, umur dan prasarana penunjang lainnya.

2. Data Sekunder yang merupakan pelengkap data-data primer meliputi data dari Dinas Pertanian, Dinas Perindagkop, Kelurahan Jaya, Kantor BPS Tidore Kepulauan, Balai Pengkajian Tanaman Pangan Maluku Utara, Koperasi Unit Desa Marimoi dan masyarakat sebagai konsumen dengan proses dialog atau wawancara untuk mengetahui faktor eksternal serta mengetahui perilaku konsumen dalam pembelian sagu kasbi. Kriteria penentuan informan dari Pemerintah adalah tingkat pendidikan dan paham serta menggeluti bidang pemasaran hasil pertanian, sedangkan kriteria konsumen adalah tingkat pendidikan minimal SMP dan umur 15 - 50 tahun, berada dalam wilayah kota Tidore Kepulauan. 


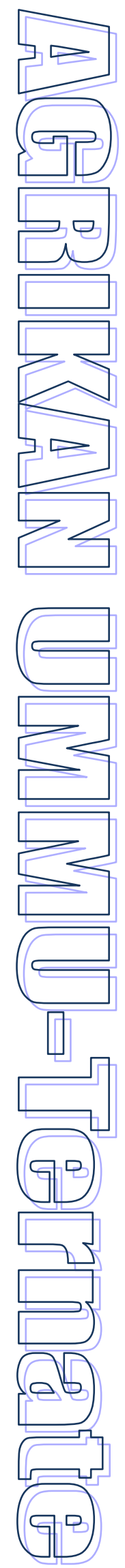

Adapun jenis data sekunder berupa data tentang luas lahan ubi kayu, produtivitas ubi kayu, keadaan umum wilayah penelitian, keadaan lahan budidaya ubi kayu, permintaan pasar dan harga pasar, jumlah industri sagu kasbi, jumlah pesaing, jumlah pemasok bahan baku ubi kayu, jumlah penduduk dan program pembinaan pemerintah yang berkaitan dengan pengembangan sagu kasbi serta perilaku konsumen dalam pembelian sagu kasbi.

Teknik pengumpulan data adalah sebagai berikut : 1) Teknik daftar pertanyaan dilakukan dengan cara datang langsung ke lokasi penelitian dan memberikan beberapa daftar pertanyaan kepada informan yang berhubungan dengan strategi pemasaran sagu kasbi yang ada di daerah tersebut. 2) Metode observasi yaitu dengan mengadakan pengamatan langsung pada objek yang ada hubungannya dengan masalah yang akan dibahas. 3) Metode wawancara yaitu dengan melakukan interviú atau tanya jawab dengan pihak-pihak yang terlibat dalam penelitian ini. 4) Diskusi terfokus (Fokus Group Discussion) yaitu kelompok diskusi yang terdiri dari seluruh informan yang akan diwawancarai dan bertujuan untuk pembobotan serta pemberian rating terhadap faktorfaktor peluang, ancaman, kekuatan dan kelemahan. 5) Dokumentasi yaitu dengan melakukan pencatatan dan pengambilan foto-foto yang berkaitan dengan penelitian ini.

Metode pengolahan dan analisis data yang digunakan adalah pendekatan konsep manajemen strategis. Analisis data dilakukan secara kualitatif dan disajikan dalam bentuk tabel, bagan dan uraian. Proses pengumpulan data dilakukan dengan metode Focus Group Discussion (FGD) yang selanjutnya dimasukkan ke dalam matriks SWOT untuk melihat strategi yang mana tepat untuk diterapkan oleh perusahaan yang memiliki unit-unit bisnis.

\section{HASIL DAN PEMBAHASAN \\ 3.1. Profil Gapoktan Prima Jaya}

Keberadaan kelompok tani dirasakan pentingnya oleh petani di Kelurahan Jaya Kecamatan Tidore Utara Kota Tidore Kepulauan sehingga minat mereka untuk membentuk kelompok tani cukup besar didukung oleh pemerintah setempat. Walaupun kelompok ini belum memiliki pembagian tugas yang jelas, namun kelompok telah berjalan dengan rasa gotong royong. Kelompok tani yang ada di Kelurahan Jaya sudah sejak tahun 1990 terbentuk dan pada awalnya hanya terdiri dari 3 kelompok tani. Seiring waktu saat ini kelompok tani telah berkembang menjadi 5 kelompok tani dengan jumlah anggota sebanyak 129 orang. Kelima kelompok tani mengelola usaha tani ubi kayu. Untuk menambah nilai jual ubi kayu, maka mereka melakukan kegiatan pengolahan ubi kayu menjadi produk pangan olahan sagu kasbi. Pemerintah melalui kegiatan Prima Tani yang dilakukan pada tahun 2007 membentuk Gapoktan (Gabungan Kelompok Tani) untuk lebih memberdayakan masyarakat tani. Pengembangan gapoktan merupakan suatu proses lanjut dari lembaga petani yang sudah berjalan baik sebagai kelompok tani. Gapoktan diposisikan sebagai lembaga yang mengkoordinasi lembaga-lembaga fungsional yang berada dibawahnya yaitu kelompok tani.

Gapoktan Prima Jaya merupakan bentuk kelembagaan gabungan dari beberapa kelompok tani yang berhubungan dengan sektor pertanian. Gapoktan Prima Jaya berdiri pada tanggal 21 November 2007 yang bergerak dibidang kegiatan pengolahan ubi kayu menjadi pangan olahan sagu kasbi. Gapoktan ini berkedudukan di Kelurahan Jaya Kecamatan Tidore Utara Kota Tidore Kepulauan. Visi dari Gapoktan Prima Jaya adalah "Menjadi Gapoktan yang dapat meningkatkan kesejahteraan hidup petani". Selain dari visi, gapoktan Prima jaya juga mengemban misi yaitu "meningkatkan keterampilan petani dan memasarkan produk pertanian yang berkualitas". Adapun tujuan dari Gapoktan ini adalah membangun pertanian untuk meningkatkan kesejahteraan bersama. Gapoktan Prima Jaya memiliki struktur organisasi terdiri dari ketua, sekertaris, bendahara, dan unit-unit usaha. Unit-unit usaha ini yang dapat berfungsi untuk memenuhi kebutuhan anggota kelompok tani dalam mengembangkan kegiatan agribisnis. Pengangkatan pengurus lengkap Gapoktan Prima Jaya berdasarkan atas rapat anggota yang dilaksanakan pada tanggal 31 Desember 2007 yang bertempat di Klinik Agribisnis Prima Tani Kelurahan Jaya. Semua anggota memiliki hak yang sama untuk diangkat menjadi pengurus Gapoktan sesuai dengan persyaratan yang telah ditetapkan. Gabungan Prima Jaya merupakan gabungan dari 5 kelompok tani yang berada di Kelurahan Jaya Kota Tidore Kepulauan. Kelompok tani yang tergabung sebagai anggota Gapoktan Prima Jaya diantaranya: kelompok tani Piga Raja yang diketuai oleh Noho Usman, Kelompok tani Ruru Saya yang diketuai oleh Abdullah Armaya, Kelompok tani Doka Saya diketuai oleh Maya Joho, Kelompok tani Rakomoi diketuai oleh Kamaruddin Hamja, Kelompok tani Tolaha diketuai oleh Jafar Aman. 


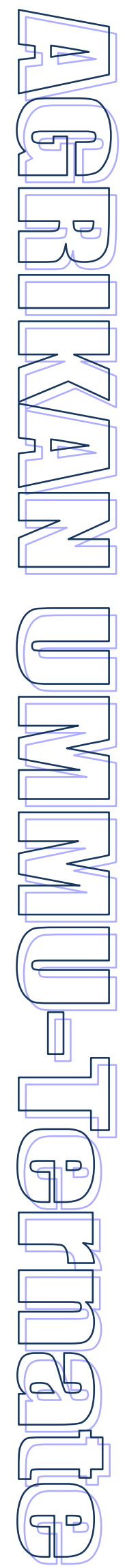

Jumlah anggota keseluruhan gapoktan adalah 129 orang. Dengan adanya jumlah anggota yang banyak ini merupakan potensi sumberdaya manusia bagi Gapoktan dalam mengembangkan usaha pengolahan sagu kasbi. Kegiatan pelatihan yang telah dilakukan oleh Gapoktan Prima Jaya bagi anggotanya berupa pelatihan dan pengembangan keterampilan pengolahan sagu aneka rasa dan pelatihan pengembangan sirup pala dengan bekerjasama Balai Pengkajian Tanaman Pangan Maluku Utara. Sementara untuk koordinasi setiap kegiatan yang akan dilakukan para angota beserta ketua kelompok tani lebih suka mengadakan musyawarah atau pertemuan setiap malam jumat di rumah ketua gapodaktan atau salah satu anggota gapoktan.

\subsection{Peranan Gapoktan Prima Jaya dalam Manajemen Operasional Pengolahan Sagu Kasbi}

Untuk melihat peranan Gapoktan Prima Jaya, maka ada 6 indikator yang dapat dijadikan tolak ukur yang digunakan, oleh karena itu dilakukan FGD dengan ketua, pengurus dan anggota Gapoktan.

Indikator pertama untuk melihat peranan Gapoktan Prima Jaya adalah melihat kemampuan Gapoktan merencanakan kegiatan. Rencana kegiatan Gapoktan Prima Jaya merupakan rencana kerja yang telah diputuskan melalui suatu rapat atau pertemuan dengan anggota dan dilaksanakan secara partisipatif. Rencana kerja gapoktan Prima Jaya ditetapkan oleh pengurus melalui rapat anggota dan menjadi dasar pengelola dalam pengembangan usaha dan bisnis gapoktan. Selain itu kegiatan perencanaan meliputi pergiliran waktu tanam, jenis varietas yang akan ditanam, sumber dan besaran modal serta tahapan dalam proses perencanaan.

Indikator kedua untuk melihat peranan Gapoktan Prima Jaya adalah melihat kemampuan Gapoktan melaksanakan dan menaati perjanjian dengan pihak lain. Setiap organisasi membutuhkan adanya pihak lain untuk bekerjasama dalam pengembangan usaha. Kemampuan melaksanakan dan menaati perjanjian dengan pihak lain merupakan aspek yang penting dalam menjalin kejasama yang saling menguntungkan. Kemampuan melaksanakan dan menaati perjanjian dengan pihak lain meliputi kemampuan kelompok tani dalam menjalin kerjasama dengan pihak lain sesuai dengan kesepakatan dan ketaatan anggota kelompok tani terhadap jadwal kegiatan yang telah dibuat melalui musyawarah dan telah dituangkan dalam rencana kerja. Gapoktan Prima Jaya melakukan kerjasama dengan BPTP Maluku Utara. Bentuk kerjasama yang pernah dilakukan Gapoktan yaitu dengan melakukan kegiatan pelatihan dan pembinaan mengenai pengembangan sagu aneka rasa dengan pihak BPTP Maluku Utara. Dalam kegiatan pelatihan tersebut, anggota gapoktan diharapkan benarbenar mengikuti dengan serius sehingga dapat menerapkannya demi peningkatan nilai jual dari sagu kasbi tersebut.

Indikator ketiga untuk melihat peranan Gapoktan Prima Jaya adalah melihat kemampuan Gapoktan memupuk modal dan memanfaatkannya secara rasional. Kemampuan memupuk modal bagi kelompok tani bertujuan untuk meningkatkan kemandirian, mengembangkan usahatani, menumbuhkan pola hidup hemat dan meningkatkan kemampuan mengatasi resiko usaha. sumber modal usaha Gapoktan berasal dari dana intern artinya hanya mengandalkan dari anggota sendiri. Usaha yang ditempuh Gapoktan Prima Jaya dalam kegiatan pemupukan modal yaitu dengan adanya dana awal serta dana iuran setiap malam Jumat sebesar Rp.1000 yang mana diwajibkan setiap anggota gapoktan. Berdasarkan hasil pengamatan, selama ini setiap anggota tetap aktif membayar iuran setiap minggunya dan dana ini dipergunakan apabila ada kegiatan sosial yang dilakukan oleh kelompok tani maupun gapoktan. Berdasarkan dana iuran yang dikumpulkan setiap malam Jumat, maka menurut keterangan bendahara (ibu Habiba) Gapoktan Prima Jaya saat ini memiliki kas modal sebesar Rp.8.650.000 untuk membiayai kegiatan-kegiatan sosial dan memberikan bantuan kepada anggotanya. Pendapatan yang diperoleh anggota Gapoktan Prima Jaya dimanfaatkan untuk kebutuhan usahatani dan pengolahan sagu kasbi berikutnya serta kebutuhan keluarga sehari-hari. Selama ini Gapoktan Prima Jaya belum pernah menerima bantuan modal usaha sedangkan pendapatan yang diperoleh masih sedikit, oleh karena itu berbagai upaya perlu dilakukan untuk mendapatkan bantuan dalam bentuk modal usaha.

Indikator keempat untuk melihat peranan Gapoktan Prima Jaya adalah melihat kemampuan Gapoktan meningkatkan hubungan yang melembaga dengan Koperasi Unit Desa (KUD) atau Koperasi Tani (Koptan). Koperasi Unit Desa Marimoi yang berada di Kelurahan Jaya memiliki diharapkan mampu berperan dalam membantu petani yang tergabung dalam anggota gapoktan serta masyarakat dalam mendukung 


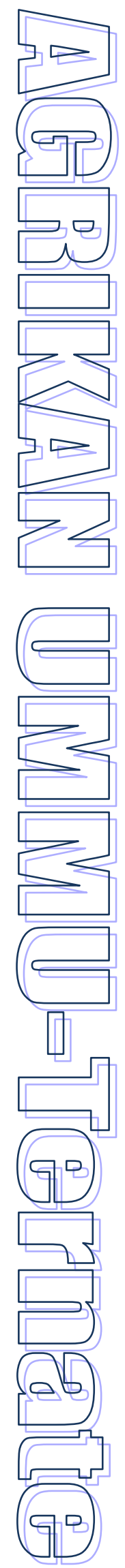

perekonomian dan ketahanan pangan. Peranan KUD diharapkan dapat bertindak sebagai pembeli produk sagu kasbi untuk dijual kembali dengan harga yang sesuai dengan harga pasar. Gapoktan Prima Jaya belum melakukan kerjasama dengan Koperasi Unit Desa Marimoi yang ada di Kelurahan Jaya. KUD Marimoi saat ini hanya mengelola sebuah toko atau warung yang menjual berbagai kebutuhan pokok masyarakat dalam wilayah kelurahan Jaya. Pada saat produk sagu kasbi telah siap dipasarkan, para pedagang masuk ke kelurahan Jaya untuk membeli produk tersebut, para pedagang membeli dengan harga yang sangat murah yakni Rp.60.000 per 100 lempeng untuk sagu kasbi tanpa rasa. Sedangkan harga di pasaran mencapai Rp.5000/4 buah. Keberadaan koperasi Marimoi di Kelurahan Jaya belum memberikan peran yang berarti dalam menunjang keberadaan usaha pengolahan sagu kasbi. Berdasarkan hasil wawancara dengan anggota gapoktan, maka dapat diketahui bahwa mereka sangat mengharapkan adanya kerjasama dengan koperasi. Dengan kerjasama tersebut, diharapkan koperasi mampu membeli produk sagu kasbi dengan harga yang sesuai di pasaran sehingga petani produsen mendapatkan keuntungan dari hasil produk sagu kasbi. Selain itu dengan belum adanya kerjasama Gapoktan Prima Jaya dengan KUD Marimoi, maka anggota Gapoktan mengalami kesulitan dalam memperoleh bantuan modal serta pemenuhan sarana produksi berupa bahan penunjang produk sagu kasbi yang dihasilkan serta belum adanya koordinasi pemasaran sagu kasbi.

Indikator kelima untuk melihat peranan Gapoktan Prima Jaya adalah melihat kemampuan Gapoktan Indikator keempat untuk melihat peranan Gapoktan Prima Jaya adalah melihat kemampuan Gapoktan menerapkan teknologi dan memanfaatkan informasi. Kelompok tani yang tergabung dalam Gapoktan Prima Jaya harus mampu secara teratur mencari, meneruskan, menyampaikan informasi kepada anggota sehingga anggota mampu memanfaatkan/menerapkan informasi dan teknologi serta kelompok mampu mengadakan, mengembangkan dan memanfaatkan fasilitas yang ada berdasarkan informasi dan teknologi pertanian yang diperoleh. Kemampuan Gapoktan Prima Jaya memanfaatkan informasi dan menerapkan teknologi berarti menyangkut kemampuan kelompok untuk mencari, meneruskan atau menyampaikan informasi kepada anggotanya. Selain itu, kemampuan anggota menerapkan informasi dan teknologi yang diterima pada kegiatan usaha tani dan pengolahan sagu kasbi diharapkan agar kelompok dapat menyediakan, mengembangkan dan memanfaatkan fasilitas yang ada. penyampaian informasi dari pengurus Gapoktan Prima Jaya kepada anggotanya dilakukan pada saat bertemu setiap malam Jumat yang dilakukan secara bergilir di rumah pengurus ataupun anggota Gapoktan Prima Jaya. penerapan teknologi dalam pengolahan sagu kasbi yang dilakukan oleh anggota Gapoktan Prima Jaya masih menggunakan peralatan dengan teknologi yang sederhana, hal ini terlihat dalam proses pembuatan sagu kasbi dimana masih menggunakan selembar seng untuk memanggang sagu kasbi, alat cetakan dari tanah liat, tungku dari batu, alat penutup cetakan dari daun coklat, alat pembersih cetakan dari kayu yang ujungnya diikatkan kulit jagung kering, nampi tempat sagu terbuat dari ranting kelapa yang kering.

Indikator keenam untuk melihat peranan Gapoktan Prima Jaya adalah melihat kemampuan Gapoktan Indikator keempat untuk melihat peranan Gapoktan Prima Jaya adalah melihat kemampuan Gapoktan menerapkan bauran pemasaran dalam pengembangan pemasaran sagu kasbi.Kemampuan Gapoktan Prima Jaya menerapkan bauran pemasaran dalam pengembangan sagu kasbi sangat diperlukan, agar produk yang dihasilkan dapat memasuki pasar sasaran dan sampai ke tangan konsumen. Marketing mix merupakan kombinasi variabel atau kegiatan yang merupakan inti dari pemasaran yang dapat dikendalikan untuk mempengaruhi reaksi pembeli atau konsumen. Produk yang dihasilkan oleh Gapoktan Prima Jaya terdiri dari dua yaitu sagu kasbi tanpa rasa dan sagu kasbi aneka rasa seperti rasa coklat, strawberry, jeruk, mangga dan lain-lain tergantung selera konsumen. Sagu kasbi tanpa rasa berwarna putih dengan bentuk persegi panjang yang tipis yang memiliki ukuran panjang $18 \mathrm{~cm}$, lebar $10 \mathrm{~cm}$ dan tebal $1 \mathrm{~cm}$. Produk ini dipasarkan dengan tidak menggunakan kemasan, para pedagang biasanya membeli produk ini dengan menggunakan karung untuk membungkus sagu kasbi dan membawanya ke pasar untuk dijual. Jumlah produksi rata-rata setiap anggota per minggunya adalah sebesar 300 lempeng yang dibuat dari $30 \mathrm{~kg}$ ubi kayu mentah yang belum diparut. Sedangkan dalam satu minggunya ada sekitar 30 anggota gapoktan yang mengolah sagu kasbi. Dengan demikian dapat diketahui bahwa jumlah ketersediaan sagu kasbi tanpa rasa setiap 


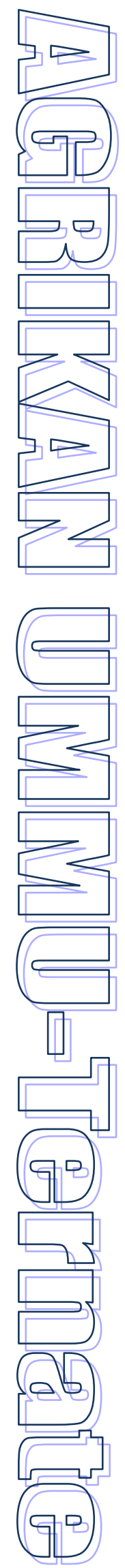

minggunya sebanyak 900 lempeng dari 30 anggota yang memproduksi sagu kasbi tanpa rasa. Jumlah produksi sagu kasbi tanpa rasa yang diproduksi oleh anggota gapoktan dalam satu bulannya sebanyak 36.000 lempeng yang dipasarkan di dalam wilayah Kota Tidore Kepulauan. Bentuk sagu kasbi persegi panjang yang tipis, untuk sagu kasbi aneka rasa memiliki ukuran panjang $8 \mathrm{~cm}$, lebar $3 \mathrm{~cm}$ dan tebal $\mathrm{cm}$. Produk sagu rasa memiliki warna yang bermacam-macam sesuai dengan kandungan rasanya. Sagu rasa strawbery berwarna pink, sagu rasa coklat berwarna coklat, sagu rasa mangga berwarna orange muda, sagu rasa melon berwarna hijau muda, sagu rasa jeruk berwarna orange. Produk sagu kasbi aneka rasa memiliki nilai jual yang tinggi yakni Rp.10.000 per bungkus, sedangkan untuk sagu kasbi tawar ditingkat produsen dijual dengan harga Rp.60.000 per 100 buah kepada pedagang pengecer di pasar. Harga sagu kasbi tawar Rp.60.000 per 100 biji juga berlaku untuk konsumen yang langsung mendatangi tempat produksi sagu kasbi. Harga sagu kasbi tawar berada pada harga tertinggi apabila di waktu musim panen cengkeh dimana harganya bisa mencapai Rp.100.000 per 100 buah. Untuk harga sagu tawar ditingkat konsumen berada pada harga Rp.5000 per 4 lempeng. Produsen yang sekaligus anggota gapoktan dalam melakukan pemasaran produk kurang melaksanakan kegiatan promosi untuk memperkenalkan jenis produk sagu kasbi. Lembaga pemasaran yang terlibat dalam perdagangan sagu kasbi di Kota Tidore Kepulauan langsung melalui pedagang pengecer ke tangan konsumen, tidak ada pihak sebagai pedagang pengumpul. Para pedagang pengecer ada yang berasal dari luar kelurahan Jaya dan ada pula yang berasal dari kelurahan Jaya sendiri. Pedagang pengecer merupakan pedagang yang langsung berhubungan dengan konsumen yang biasanya mereka menjual di pasar baik pasar kabupaten/kota maupun pasar kecamatan. Petani sebagai produsen sagu kasbi biasanya membuat sagu kasbi pada hari jumat dan sabtu, oleh karena pasar yang ada di Kecamatan adalah pasar minggu. Dengan demikian pedagang pengecer biasanya mendatangi lokasi pembuatan sagu kasbi pada hari sabtu dan minggu. Sedangkan pasar yang ada di Kabupaten/kota adalah pasar hari selasa dan kamis. Para pedagang pengecer tersebut umumnya adalah langganan tetap dari petani yang sudah bekerjasama sejak lama. Pasar yang ada di Kecamatan berjarak 5 km dari lokasi pembuatan sagu kasbi, sedangkan pasar yang ada di kota berjarak $28 \mathrm{~km}$.Berdasarkan pembahasan mengenai peranan gapoktan Prima Jaya dalam manajemen operasional pengembangan pemasaran sagu kasbi terlihat bahwa dari 6 tolak ukur yang digunakan hanya 2 indikator yang sudah memiliki kemampuan penerapannya cukup baik, sedangkan 4 diantaranya masih membutuhkan peningkatan kemampuan untuk mencapai tujuan yang telah ditetapkan secara bersama-sama. Dengan demikian peranan Gapoktan Prima Jaya belum maksimal dalam manajemen operasional pengembangan pemasaran sagu kasbi.

\subsection{Perilaku Konsumen dalam Pembelian Sagu Kasbi}

Perilaku konsumen dalam membeli sagu kasbi dipengaruhi oleh beberapa faktor diantaranya harga yang berlaku dipasaran serta bentuk penampilan sagu kasbi. Pada saat harga sagu kasbi murah biasanya mereka membeli dalam jumlah yang banyak, oleh karena semua anggota keluarga menyukai produk sagu kasbi. Selain itu faktor budaya juga mempengaruhi, oleh karena sejak dahulu turun-temurun mereka sudah terbiasa dengan budaya mengkonsumsi sagu kasbi sebagai makanan pengganti nasi. Bahkan dari pengakuan konsumen ada yang mengatakan bahwa mereka tidak sanggup memakan nasi setiap hari dalam satu bulannya harus diselingi dengan mengkomsumsi sagu kasbi.

\subsection{Analisis Faktor Lingkungan Strategis \\ 3.4.1. Faktor Internal}

Beberapa faktor internal yang berpengaruh terhadap pemasaran sagu kasbi di Kecamatan Tidore Utara, Kota Tidore Kepulauan terdiri dari kekuatan (strengths) dan kelemahan (weakness).

\section{a. Kekuatan (strengths)}

1. Keterampilan Petani, Keterampilan dalam membuat sagu kasbi sudah diperoleh secara turun temurun dari orang tua mereka, sehingga produsen setempat sudah sangat cakap dalam membuat sagu kasbi..

2. Daya tahan sagu kasbi, Produk sagu kasbi sebagai makanan alternatif non beras yang sangat menunjang program diversifikasi pangan Produk sagu kasbi baik yang aneka rasa maupun yang tawar memiliki tekstur yang keras dan kering.

3. Jumlah anggota yang banyak, Berdasarkan wawancara dengan ketua Gapoktan, diketahui anggota gapoktan merupakan petani ubi kayu yang memiliki anggota sebanyak 129 orang 


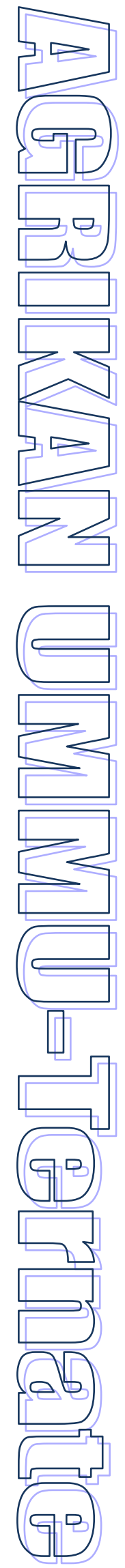

dan tidak semua anggota mengolah ubi kayu menjadi sagu kasbi hanya sekitar 85 orang saja.

4. Ketersediaan bahan baku, Berdasarkan wawancara dengan anggota gapoktan, diketahui bahwa tanaman ubi kayu banyak dibudidayakan oleh masyarakat setempat dan hampir di setiap jalan memasuki wilayah kelurahan Jaya ditanami ubi kayu. Produsen sagu kasbi juga merupakan petani yang menanam ubi kayu, jadi dari hasil panen ubi kayu itulah mereka mengolahnya menjadi sagu kasbi.

5. Potensi genetis ubi kayu, Berdasarkan wawancara dengan Kepala BPTP Maluku Utara, diketahui bahwa Tidore merupakan daerah yang memiliki kemantapan potensi genetis ubi kayu, hal ini telah dibuktikan dengan adanya uji kemantapan genetis ubi kayu antara klon ternate, klon tidore dengan varietas nasional UJ-5 yang dilakukan oleh Balai Pengkajian Teknologi Pertanian (BPTP).

6. Diversifikasi produk, Pada awalnya produk yang dihasilkan oleh anggota gapoktan adalah sagu kasbi tawar atau tanpa rasa. Dengan adanya hasil pelatihan yang dilakukan oleh BPPT Maluku Utara mengenai pengembangan rasa sagu kasbi, maka produk sagu kasbi dikembangkan dengan berbagai macam rasa yaitu rasa coklat, mangga, strawberry dan jeruk.

\section{b. Kelemahan (weakness)}

1. Kegiatan promosi kurang, Produk sagu kasbi khususnya yang diproduksi oleh Gapoktan Prima Jaya di Kelurahan Jaya sudah lama dikenal dan dikonsumsi oleh penduduk setempat di Kota Tidore Kepulauan tetapi belum begitu dikenal di luar wilayah Tidore.

2. Keterbatasan modal usaha, Keterbatasan modal usaha dalam kegiatan pengolahan ubi kayu menjadi sagu kasbi sangat mempengaruhi kelangsungan usaha tersebut. Berdasarkan wawancara dengan anggota gapoktan menunjukkan bahwa modal yang dimiliki oleh anggota gapoktan sangat terbatas, hal ini dapat dilihat dari ketidakmampuan produsen membuat sagu kasbi rasa jika tidak ada yang pesan.

3. Pelaksanaan tugas dalam struktur organisasi masih kurang,Gapoktan Prima Jaya memiliki struktur organisasi yang terdiri dari ketua, sekertaris, bendahara dan berbagai jenis bidang unit usaha seperti produksi, pasca panen, pengelolaan keuangan, pemasaran dan jasa penunjang.

4. Kemasan masih sederhana,Produk sagu kasbi tanpa rasa dipasarkan tanpa menggunakan kemasan, biasanya para pedagang pengecer di pasar hanya menutupinya dengan plastik atau daun pisang.

5. Peralatan yang digunakan masih sederhana,Anggota gapoktan sebagai produsen sagu kasbi masih mempergunakan peralatan yang sederhana dalam mengolah ubi kayu menjadi sagu kasbi. Berdasarkan wawancara dengan anggota gapoktan, bahwa peralatan yang digunakan masih sederhana.

6. Akses pasar kurang, Daerah pemasaran sagu kasbi yang diproduksi oleh anggota Gapoktan Prima Jaya untuk saat sekarang ini adalah sifatnya lokal hanya menjangkau wilayah Kota Tidore Kepulauan dan wilayah sekitar Tidore seperti Ternate.

7. Belum adanya kerjasama gapoktan dengan KUD, Koperasi Unit Desa (KUD) Marimoi merupakan koperasi unit desa yang ada di Kelurahan Jaya.

\subsubsection{Faktor Eksternal}

Beberapa faktor eksternal yang berpengaruh terhadap pemasaran sagu kasbi di Kecamatan Tidore Utara, Kota Tidore Kepulauan terdiri dari peluang (opportunities) dan ancaman (threaths).

\section{a. Peluang (opportunities)}

1. Minat konsumen meningkat, Meningkatnya permintaan konsumen terhadap suatu barang atau produk dipenagruhi oleh beberapa hal seperti pendapatan, selera dan kebutuhan dan lainlain.

2. Letak geografis yang strategis,Kota Tidore Kepulauan merupakan daerah kepulauan yang memiliki letak geografis yang sangat strategis, yakni berada dekat dengan kota Ternate sebagai pusat perekonomian di wilayah Maluku Utara, sehingga arus perpindahan barang dari Tidore ke Ternate lebih lancar.

3. Kesesuaian iklim dengan tanaman, Kota Tidore khususnya Kelurahan Jaya memiliki kondisi lingkungan cukup basah dengan tekstur tanah halus, $\mathrm{pH}$ agak masam, kesuburan tanah baik serta komposisi landfrom tanah vulkanik yang cocok untuk ubi kayu.

4. Pertumbuhan penduduk, Hasil sensus penduduk pada tahun 2009 menunjukkan bahwa jumlah penduduk di Kota Tidore 


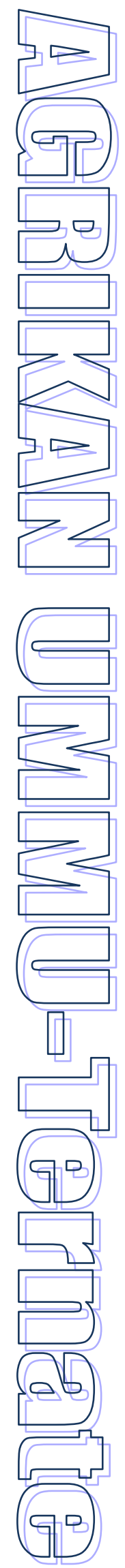

Kepulauan sebanyak 94.035 jiwa sedangkan pada tahun 2008 berjumlah 91.930.

5. Kondisi politik yang kondusif, Berdasarkan hasil wawancara dengan anggota Gapoktan, maka diketahui bahwa pemerintah dalam hal ini Pemerintah Kota memegang peranan yang sangat penting dalam menciptakan lingkungan usaha yang kondusif.

6. Perkembangan teknologi informasi, Perkembangan teknologi informasi sangat besar pengaruhnya terhadap pengembangan pemasaran sagu kasbi.

b. Ancaman (threaths)

1. Banyaknya produk sejenis, Di Kota Tidore Kepulauan banyak jenis sagu diantaranya sagu lempeng dari ubi kayu tetapi diproduksi dari kabupaten lain serta sagu lempeng berwarna coklat dari pohon sagu.

2. Kondisi jalan yang tidak memadai, kondisi jalan menuju pasar baik pasar kecamatan maupun pasar kabupaten/kota kurang memadai, banyak yang berlubang-lubang sehingga resiko kerusakan dalam proses pengangkutan sagu kasbi cukup besar. Dengan demikian mereka sangat mengharapkan dukungan pemerintah dalam memperbaiki sarana dan prasarana jalan untuk memperlancar transportasi produk.

3. Pengaruh globalisasi, Pengaruh globalisasi dapat menjadi ancaman bagi kelangsungan usaha sagu kasbi, karena ketidaksiapan atau ketidakmampuan dalam menyikapi aturan-aturan atau ketentuanketentuan yang ada seperti misalnya standarisasi mutu barang perdagangan internasional ISO 9000, 2000 atau sistem manajemen mutu lingkungan ISO 1400. Sedangkan usaha sagu kasbi ini belum ada penetapan standarisasi mutu.

\subsection{Matriks SWOT}

Tahap selanjutnya yang dilakukan setelah mengidentifikasi kondisi lingkungan internal dan eksternal Gapoktan Prima Jaya adalah merumuskan strategi. Perumusan strategi dilakukan dengan menyusun matriks SWOT Tabel 1).

a. Strategi SO, Strategi SO merupakan alternatif strategi yang menggunakan kekuatan internal Gapoktan untuk meraih peluang yang ada di luar Gapoktan. Strategi
SO yang dihasilkan adalah "Pengembangan produk sagu kasbi aneka rasa"

b. Strategi WO, Strategi WO merupakan alternatif strategi yang dilakukan dengan meminimalkan kelemahan yang dimiliki oleh Gapoktan Prima Jaya dengan memanfaatkan peluang yang ada secara maksimal. Strategi WO yang dihasilkan adalah sebagai berikut : 1).Menciptakan atribut produk yang menarik 2) Melakukan kegiatan promosi dengan memanfaatkan perkembangan informasi 3) Membina kerjasama dengan KUD dalam bidang pemasaran sagu kasbi

c. Strategi ST, Strategi ST merupakan strategi yang menggunakan kekuatan yang dimiliki oleh gapoktan untuk menghindari dampak dari ancaman yang dihadapi. Strategi ST yang dihasilkan adalah sebagai berikut "Menciptakan merek produk sagu kasbi yang berbeda dengan pesaing"

d. Strategi WT, Strategi WT merupakan alternatif strategi yang bisa diterapkan gapoktan dengan meminimalkan kelemahan yang dimiliki untuk menghindari ancaman yang dihadapinya. Strategi WT yang dihasilkan adalah "Melakukan pengembangan pasar agar terjangkau konsumen di era globalisasi"

\section{KESIMPULAN DAN SARAN}

Berdasarkan hasil penelitian, maka dapat dapat diambil beberapa kesimpulan antara lain sebagai berikut : 1)Peranan Gapoktan Prima Jaya belum maksimal dalam manajemen operasional pengembangan pemasaran sagu kasbi. Oleh karena dari 6 indikator untuk menilai peran gapoktan dalam manajemen operasional pemasaran sagu kasbi hanya 2 indikator yang telah diterapkan cukup baik sedangkan 4 indikator lainnya masih perlu peningkatan penerapan yang lebih maksimal. 2) Strategi yang perlu dilakukan oleh Gapoktan Prima Jaya dalam pengembangan pemasaran sagu kasbi meliputi 1) Pengembangan produk sagu kasbi dengan aneka rasa pandan, kenari dan gula merah, 2) Menciptakan atribut produk yang menarik, 3) melakukan promosi, 4) membina kerjasama dengan KUD, 5) Menciptakan merek produk sagu kasbi yang berbeda dengan pesaing, 6) Melakukan pengembangan pasar. Berdasarkan hasil penelitian disarankann kepada Gapoktan Prima Jaya untuk membina kerjasama dengan Koperasi Unit Desa sebagai lembaga ekonomi yang berada di pedesaan untuk meningkatkan 
pendapatan anggota gapoktan sebagai produsen sagu kasbi serta aktif melakukan kegiatan promosi untuk memperkenalkan produk sagu kasbi.Berdasarkan hasil penelitian ini disarankan kepada Pemerintah Kota Tidore Kepulauan untuk memberikan dukungan berupa perbaikan sarana dan prasarana transportasi agar bisa memperlancar kegiatan pemasaran sagu kasbi.

Tabel 1. Analisis SWOT

\begin{tabular}{|c|c|c|}
\hline ANALISIS EKSTERNAL & 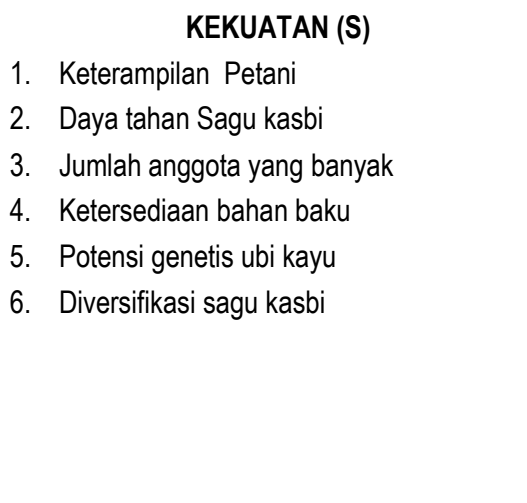 & $\begin{array}{l}\text { KELEMAHAN (W) } \\
\text { 1. Kegiatan promosi kurang } \\
\text { 2. Keterbatasan modal usaha } \\
\text { 3. Pelaksanaan tugas dalam struktur } \\
\text { organisasi masih kurang } \\
\text { 4. Kemasan masih sederhana } \\
\text { 5. Teknologi yang digunakan masih } \\
\text { sederhana } \\
\text { 6. Akses pasar kurang } \\
\text { 7. Belum adanya kerjasama gapoktan } \\
\text { dengan KUD }\end{array}$ \\
\hline $\begin{array}{l}\qquad \text { PELUANG }(0) \\
\text { 1. Minat Konsumen meningkat } \\
\text { 2. Letak geografis yang strategis } \\
\text { 3. Kesesuaian iklim } \\
\text { 4. Pertambahan penduduk } \\
\text { 5. Kondisi politik yang kondusif } \\
\text { 6. Perkembangan teknologi informasi }\end{array}$ & $\begin{array}{l}\text { STRATEGI SO } \\
\text { Pengembangan produk dengan aneka rasa } \\
\text { pandan, kenari, gula merah }(\mathrm{S} 1, \mathrm{~S} 2, \mathrm{~S} 4,52 \text {, } \\
\mathrm{O} 1, \mathrm{O} 2, \mathrm{O}, \mathrm{O} 4)\end{array}$ & $\begin{array}{l}\quad \text { STRATEGI WO } \\
\text { 1. Menciptakan atribut produk yang } \\
\text { menarik (W4,01,04) } \\
\text { 2. Melakukan kegiatan promosi dengan } \\
\text { memanfaatkan perkembangan } \\
\text { informasi (W1, 01,05,06) } \\
\text { 3. Membina kerjasama dengan KUD } \\
\text { dalam bidang pemasaran (W3,W7, } \\
\text { O5) }\end{array}$ \\
\hline $\begin{array}{l}\qquad \text { ANCAMAN (T) } \\
\text { 1. Banyaknya produk sejenis } \\
\text { 2. Kondisi jalan yang tidak memadai } \\
\text { 3. Pengaruh globalisasi }\end{array}$ & $\begin{array}{l}\text { STRATEGI ST } \\
\text { Menciptakan merek produk sagu kasbi yang } \\
\text { berbeda dengan pesaing(S4,T1) }\end{array}$ & $\begin{array}{l}\text { STRATEGI WT } \\
\text { Melakukan pengembangan pasar agar } \\
\text { terjangkau konsumen di era globalisasi } \\
(\text { W6,04) }\end{array}$ \\
\hline
\end{tabular}

\section{DAFTAR PUSTAKA}

Anonim. 2009. Agribisnis Tidore. Kota Tidore Kepulauan; Balai Pengkajian Teknologi Pertanian Maluku Utara (File;//D:/agribinis Tidore.htm di akses tanggal10 Januari 2011)

Anonim. 2010. Sagu Kasbi Aneka Rasa; Kota Tidore Kepulauan; Balai Pengkajian Teknologi Pertanian Maluku Utara (file:///D:/Pangan Olahan Sagu Kasbi 5.htm).

Basu Swasta, 1991. Azas-Azas Marketing, Edisi Kedua, Liberty, Yogyakarta.

Balai Pengkajian Tanaman Pangan, 2010. Sagu Aneka Rasa, Vol.3 Nomor 4, diakses 29 Januari 2011)

Downey, W. David dan Steven, P. Ericson. 1992. Manajemen Agribisnis.Terjemahan Edisi 2, Erlangga, Jakarta.

David, Fred R. 2001. Manajemen Strategis. Prenhallindo, Jakarta

Hermanto dan Subowo, G. 2006. Modal, Sistem dan Usaha Agribisnis di Lahan Rawa Pasang Surut: Konsepsi dan Strategi Pengembangannya. Makalah ini disampaikan pada Seminar Pengelolaan Hutan dan Lahan Rawa Secara Bijaksana dan Terpadu. Badan Litbang Hutan Tanaman Palembang, 28 Maret 2006 do Hotel Swana Dwipa, Palembang.

Karim Saleh, 2002. Mata Kuliah Manajemen Agribisnis dan Agroindustri, Program Pasca Sarjana Universitas Hasanuddin, Makassar.

Kinnear,T.C dan Taylor, J.R. 1996. Riset Pemasaran, Pendekatan Terpadu, Edisi Ketiga, Erlangga, Jakarta.

Kottler, Philip. 1990. Manajemen Pemasaran (Analisis Perencanaan dan Pengendalian), Jilid Satu, Edisi Lima, Airlangga, Jakarta. 
Schiffman, L dan Kanuk, L. Lazar, 1978, Perilaku Konsumen. Terjemahan oleh Zulkifli Kasip, 2008. PT.Indeks, Jakarta

Pearce dan Robinson, 1997. Manajemen Strategik, Formulasi, Implementasi dan Pengendalian, jilid Satu, Bina Rupa Aksara, Jakarta

Rangkuti, Freddy. 2008. Analisa SWOT Teknik Membedah Kasus Bisnis, Cetakan 15, PT. Gramedia Pustaka Umum, Jakarta.

Riduwan dan Akdon, 2005. Rumus dan Data Dalam Analisis Statistika, Alfabeta, Bandung.

Rukmana, Rahmat. 1997. Ubi Kayu (Budidaya dan Pasca Panen), Kanisius, Yogyakarta.

Saragih, B. 2000. Agribisnis (Paradigma Baru Pembangunan Ekonomi Berbasis Pertanian), Mulia Persada, Jakarta.

Soekartawi, 1985. Manajemen Agribisnis, Teori Dan Aplikasinya, PT.Raja Grafindo Persada, Jakarta Sofyan Assauri, 2009. Manajemen Pemasaran, PT.Raja Grafindo Persada, Jakarta

Staton, William, J. 1991. Fundamentals of Marketing, Fiffty Edition, Mc Graw Hill Book Company, Tokyo.

Suteja, Siswanto. 1991. Kerangka Dasar Manajemen Pemasaran, Cetakan Ketiga, Bagian Publikasi Lembaga Pendidikan dan Pembinaan Manajemen, Jakarta.

Syahyuti, 2003. Kebijakan Pengembangan Gabungan Kelompok Tani (GAPOKTAN) Sebagai Kelembagaan Ekonomi Di Pedesaan, Jurnal Analisis Kebijakan Pertanian, Volume 5 No.1 (http://pse.litbang.deptan.go.id diakses 15 Januari 2011)

Tjiptono, Fandy, 2008. Strategi Pemasaran, Edisi Ketiga, Andi, Yogyakarta

Warsana, 2009. Pemantapan Kelembagaan Pada Gapoktan, Artikel Tabloid Sinar Tani, (http://www.sinartani.com diakses 16 Januari 2011), Jawa Tengah

Winardi, 1990. Azas-Azas Marketing, Alumni Bandung. 